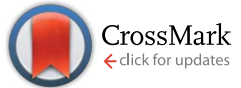

Cite this: Chem. Sci., 2017, 8, 674

Received 30th May 2016

Accepted 30th August 2016

DOI: $10.1039 / \mathrm{c6sc02382 \textrm {g }}$

www.rsc.org/chemicalscience

\section{A low-crystalline ruthenium nano-layer supported on praseodymium oxide as an active catalyst for ammonia synthesis $\dagger$}

\author{
Katsutoshi Sato, ${ }^{\text {ab }}$ Kazuya Imamura, t $^{\mathrm{b}}$ Yukiko Kawano, ${ }^{\mathrm{b}}$ Shin-ichiro Miyahara, ${ }^{a}$ \\ Tomokazu Yamamoto, ${ }^{c}$ Syo Matsumura ${ }^{\mathrm{c}}$ and Katsutoshi Nagaoka*b
}

\begin{abstract}
Ammonia is a crucial chemical feedstock for fertilizer production and is a potential energy carrier. However, the current method of synthesizing ammonia, the Haber-Bosch process, consumes a great deal of energy. To reduce energy consumption, a process and a substance that can catalyze ammonia synthesis under mild conditions (low temperature and low pressure) are strongly needed. Here we show that $\mathrm{Ru} / \mathrm{Pr}_{2} \mathrm{O}_{3}$ without any dopant catalyzes ammonia synthesis under mild conditions at 1.8 times the rates reported with other highly active catalysts. Scanning transmission electron micrograph observations and energy dispersive $\mathrm{X}$ ray analyses revealed the formation of low-crystalline nano-layers of ruthenium on the surface of $\operatorname{Pr}_{2} \mathrm{O}_{3}$. Furthermore, $\mathrm{CO}_{2}$ temperature-programmed desorption revealed that the catalyst was strongly basic. These unique structural and electronic characteristics are considered to synergistically accelerate the rate-determining step of $\mathrm{NH}_{3}$ synthesis, cleavage of the $\mathrm{N} \equiv \mathrm{N}$ bond. We expect that the use of this catalyst will be a starting point for achieving efficient ammonia synthesis.
\end{abstract}

\section{Introduction}

Ammonia is one of the most important feedstocks in the modern chemical industry. Globally, $>80 \%$ of ammonia produced is used to produce fertilizer, which is essential for growing crops. ${ }^{1}$ In addition, ammonia has recently attracted attention as a carrier of energy and hydrogen..$^{2-5}$ Ammonia is produced by combining atmospheric $\mathrm{N}_{2}$ with hydrogen produced by renewable energy. The ammonia is liquefied and transported to where it is used to generate power in engines or electricity in fuel cells. Ammonia is being considered as a carrier of energy and hydrogen because, (1) it has a high energy density $\left(12.8 \mathrm{GJ} \mathrm{m}^{-3}\right.$ ) and (2) a high hydrogen content (17.6 wt\%), and (3) carbon dioxide is not released when hydrogen is produced by ammonia decomposition. ${ }^{2}$ If ammonia can be produced efficiently from renewable energy, it can contribute to the solution of global problems related to energy and food production.

${ }^{a}$ Elements Strategy Initiative for Catalysts and Batteries, Kyoto University, 1-30 Goryo-Ohara, Nishikyo-ku, Kyoto 615-8245, Japan

${ }^{b}$ Department of Applied Chemistry, Faculty of Engineering, Oita University, 700 Dannoharu, Oita 870-1192, Japan.E-mail: nagaoka@oita-u.ac.jp

${ }^{c}$ Department of Applied Quantum Physics and Nuclear Engineering, Kyushu University, 744 Motooka, Nishi-ku, Fukuoka 819-0395, Japan

$\dagger$ Electronic supplementary information (ESI) available: Detailed procedures for each method, catalytic performance, STEM-EDX images, detailed characterization. See DOI: 10.1039/c6sc02382g

\$ Present address: Research Laboratory of Hydrothermal Chemistry, Faculty of Science, Kochi University. 2-5-1 Akebono-cho, Kochi 780-8520, Japan.
Currently, most ammonia is synthesized via the HaberBosch process. ${ }^{6-8}$ This process is a major consumer of energy, accounting for about $1 \%$ of global energy consumption. In this process, about $60 \%$ of consumed energy is recovered and saved in ammonia as enthalpy. However, the remaining energy is lost, mainly during the production of hydrogen from natural gas, ammonia synthesis, and gas separation. Because ammonia synthesis is carried out at very high temperatures $\left(>450{ }^{\circ} \mathrm{C}\right)$ and high pressures ( $>20 \mathrm{MPa})$, a major goal is the reduction of the high amount of energy used in this process. ${ }^{9}$ Curbing global energy consumption requires, inter alia, a catalyst that is able to produce ammonia at much lower temperatures and pressures than required for the iron-based catalysts used in the HaberBosch process. ${ }^{\text {10-12 }}$

Ruthenium is a possible catalyst for ammonia synthesis because of its higher activity at low pressure and temperature compared to that of iron-based catalysts. The rate-determining step in $\mathrm{NH}_{3}$ synthesis is cleavage of the $\mathrm{N} \equiv \mathrm{N}$ bond of $\mathrm{N}_{2}$, because the bond energy is very high $\left(945 \mathrm{~kJ} \mathrm{~mol}^{-1}\right) .{ }^{13,14}$ It has been reported that modification of the morphology of the $\mathrm{Ru}$ surface ("structural modification") and of the $\mathrm{Ru}$ electronic states ("electronic modification") are effective ways to accelerate the rate-determining step and thus enhance the ammoniasynthesis activity of the Ru catalyst. ${ }^{15,16}$ In the case of structural modification, the unusual unsaturated $\mathrm{B}_{5}$-type site of $\mathrm{Ru}$ has been proven to be highly active. ${ }^{17-19}$ The $B_{5}$-type site consists of five $\mathrm{Ru}$ atoms: two at step edges and three on the lower terrace. The five $\mathrm{Ru}$ atoms are all associated with the transition state of adsorbed $\mathrm{N}_{2}$, which results in weakening of the $\mathrm{N} \equiv \mathrm{N}$ bond. ${ }^{17}$ 
Adjusting the $\mathrm{Ru}$ particle size (e.g., to $5 \mathrm{~nm}$ when $\mathrm{Ru}$ particles are spherical) and changing the shape of Ru particles create an abundance of $\mathrm{B}_{5}$-type sites. ${ }^{18,20,21}$ In the case of electronic modification, the use of basic supports and the addition of a strong basic promoter to $\mathrm{Ru}$ catalysts have enhanced ammonia synthesis activity dramatically. ${ }^{15,16}$ The mechanism involves the transfer of electrons to the Ru metal from the basic components. Transfer of electrons from Ru to the antibonding $\pi$-orbitals of $\mathrm{N}_{2}$ then results in weakening of the $\mathrm{N} \equiv \mathrm{N}$ bond and promotion of $\mathrm{N} \equiv \mathrm{N}$ cleavage..$^{22}$ Weakening of the $\mathrm{N} \equiv \mathrm{N}$ bond by doping with strong basic oxides has been confirmed by observation of the $\mathrm{N} \equiv \mathrm{N}$ stretching frequency with infrared spectroscopy (IR); the most effective promoter has been reported to be $\mathrm{Cs}_{2} \mathrm{O}^{23,24}$ In fact, most of the highly active $\mathrm{Ru}$ catalysts contain $\mathrm{Cs}_{2} \mathrm{O}$ as a promoter. ${ }^{10,15,25,26}$ However, $\mathrm{CsOH}$, which may be produced in the presence of an $\mathrm{H}_{2} \mathrm{O}$ impurity in the reactant, has a low melting point $\left(272^{\circ} \mathrm{C}\right)$ and may move on the surface of the catalyst particles or vaporize under the reaction conditions, the eventual result being degradation of the catalyst. ${ }^{27}$ On the other hand, $\mathrm{BaO}$ is also reported as an effective promoter and $\mathrm{Ba}-\mathrm{Ru} /$ activated carbon $(\mathrm{Ba}-\mathrm{Ru} / \mathrm{AC})$ has been used in commercial industrial processes.$^{28}$ Recently, Horiuchi et al. reported that $\mathrm{Ru} / \mathrm{BaTiO}_{3}$ and $\mathrm{Ba}-\mathrm{Ru} / \mathrm{MgO}$ show comparable high activity to $\mathrm{Cs}-\mathrm{Ru} / \mathrm{MgO}^{26}$ Notably, Ru-loaded electride $\left[\mathrm{Ca}_{24} \mathrm{Al}_{28} \mathrm{O}_{64}\right]^{4+}\left(\mathrm{e}^{-}\right)_{4}\left(\mathrm{Ru} / \mathrm{C} 12 \mathrm{~A} 7: \mathrm{e}^{-}\right)$, which is a new class of $\mathrm{Ru}$ catalyst supported on a non-oxide, shows high $\mathrm{NH}_{3}$-synthesis

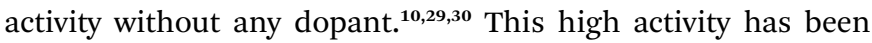
attributed to the high electron-donating power of the electride.

We show here that a praseodymium oxide-supported $\mathrm{Ru}$ catalyst $\left(\mathrm{Ru} / \mathrm{Pr}_{2} \mathrm{O}_{3}\right)$ without any dopant exhibits unparalleled $\mathrm{NH}_{3}$ synthesis ability compared with highly active catalysts reported previously. The loading of Ru on the support was characterized by an unusual morphology of low-crystalline nanolayers, and the basicity of the catalyst was very high. We show that the combination of these features facilitated the activation of $\mathrm{N}_{2}$.

\section{Results and discussion}

\section{$\mathbf{N H}_{3}$-synthesis activities of supported Ru-catalysts}

Fig. 1 compares the $\mathrm{NH}_{3}$-synthesis activity of the $\mathrm{Ru} / \mathrm{Pr}_{2} \mathrm{O}_{3}$ catalyst with that of other supported Ru catalysts under the same reaction conditions. Ba-Ru/activated carbon (Ba-Ru/AC) has been used in industrial processes; ${ }^{28} \mathrm{Cs}-\mathrm{Ru} / \mathrm{MgO}$ is one of the most active $\mathrm{Ru}$ catalysts in $\mathrm{NH}_{3}$ synthesis; ;5,31 and $\mathrm{Ru} /$ $\mathrm{C} 12 \mathrm{~A} 7: \mathrm{e}^{-}$has attracted attention as a new active $\mathrm{NH}_{3}$-synthesis catalyst. ${ }^{10-12}$ At $400{ }^{\circ} \mathrm{C}$ and $0.1 \mathrm{MPa}$ (Fig. 1a), $\mathrm{Ru} / \mathrm{Pr}_{2} \mathrm{O}_{3}$ and Cs$\mathrm{Ru} / \mathrm{MgO}$ gave $\mathrm{NH}_{3}$ yields near the thermodynamic equilibrium $(0.88 \%)$. Both the yields and $\mathrm{NH}_{3}$ production rates were higher than those achieved with the $\mathrm{Ru} / \mathrm{C} 12 \mathrm{~A} 7: \mathrm{e}^{-}$and $\mathrm{Ba}-\mathrm{Ru} / \mathrm{AC}$ catalysts. In the industrial process, it is important to obtain high one-pass $\mathrm{NH}_{3}$ yields to avoid the high energy usage required for gas separation. Furthermore, from the standpoint of thermodynamic regulation, $\mathrm{NH}_{3}$ synthesis is favored if the reaction is carried out under high pressure. ${ }^{9}$ We therefore measured the $\mathrm{NH}_{3}$-synthesis activity at $1.0 \mathrm{MPa}$ (Fig. 1b), where the $\mathrm{NH}_{3}$ yield at the thermodynamic equilibrium increases to a

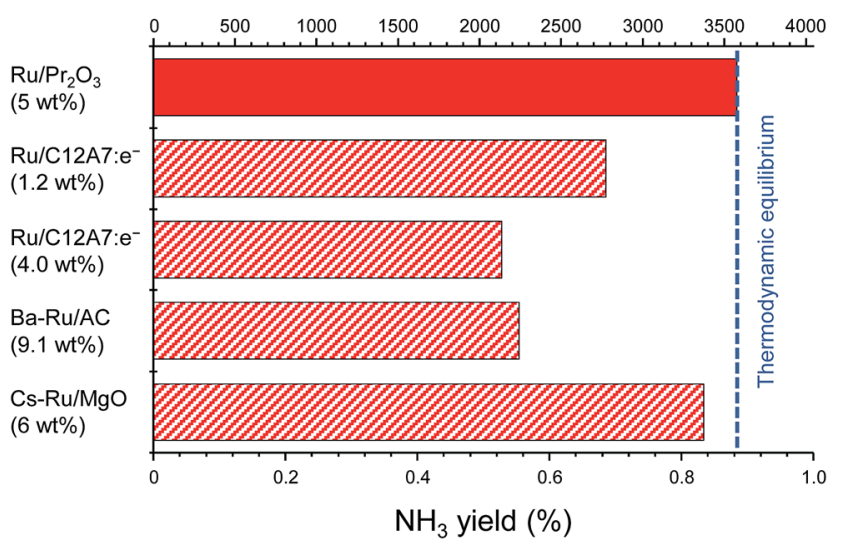

b

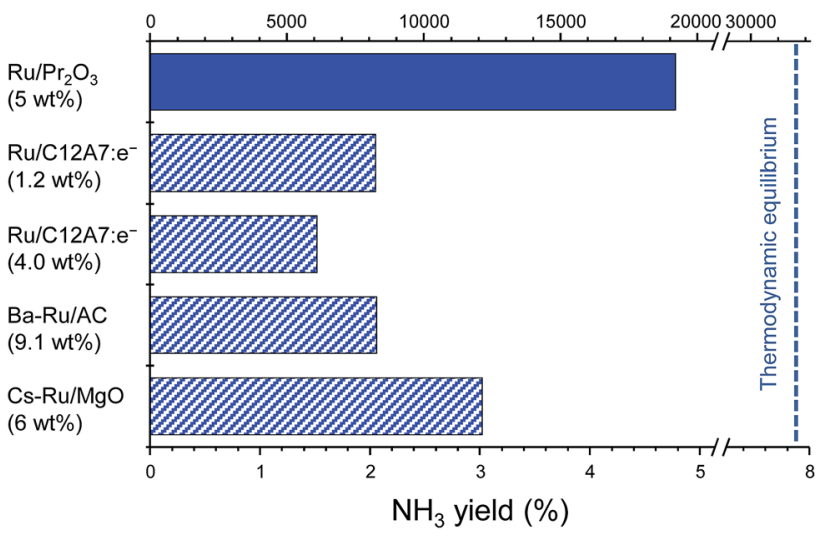

Fig. 1 Catalytic performance of supported Ru catalysts for $\mathrm{NH}_{3}$ synthesis at (a) $0.1 \mathrm{MPa}$ and (b) $1 \mathrm{MPa}$. Reaction conditions: catalyst, $0.2 \mathrm{~g}$; reactant gas, $\mathrm{H}_{2} / \mathrm{N}_{2}=3$ with a flow rate of $60 \mathrm{~mL} \mathrm{~min}^{-1}$; reaction temperature, $400{ }^{\circ} \mathrm{C}$. With the exception of $\mathrm{Ru} / \mathrm{Pr}_{2} \mathrm{O}_{3}, \mathrm{NH}_{3}$ synthesis rates are reproduced from ref. 10 .

$7.9 \%$. Note that $1.0 \mathrm{MPa}$ is still much lower than the reaction pressure used for the Haber-Bosch process. With the increase in reaction pressure, the differences in the activities of the catalysts were more pronounced: the $\mathrm{NH}_{3}$ yield reached $4.8 \%$ and the rate of formation obtained over $\mathrm{Ru} / \mathrm{Pr}_{2} \mathrm{O}_{3}$ reached $19000 \mu \mathrm{mol} \mathrm{g}^{-1} \mathrm{~h}^{-1},>1.8$ times the values associated with other catalysts.

To understand why the rates of $\mathrm{NH}_{3}$ synthesis are so high when catalyzed by $\mathrm{Ru} / \mathrm{Pr}_{2} \mathrm{O}_{3}$, we compared the characteristics of $\mathrm{Ru} / \mathrm{Pr}_{2} \mathrm{O}_{3}$ with those of $\mathrm{Ru} / \mathrm{MgO}$ and $\mathrm{Ru} / \mathrm{CeO}_{2}$. All of the catalysts were loaded with $5 \mathrm{wt} \% \mathrm{Ru}$. Among the dopant-free simple oxide-supported Ru catalysts, $\mathrm{Ru} / \mathrm{MgO}$ and $\mathrm{Ru} / \mathrm{CeO}_{2}$ have shown relatively high $\mathrm{NH}_{3}$-synthesis activity, ${ }^{32}$ and $\mathrm{CeO}_{2}$ is a rare-earth oxide like $\mathrm{Pr}_{2} \mathrm{O}_{3}$. Fig. S2 $\uparrow$ shows in-situ X-ray diffraction patterns of the catalysts after activation in pure $\mathrm{H}_{2}$ at $400{ }^{\circ} \mathrm{C}$. In the cases of $\mathrm{Ru} / \mathrm{MgO}$ and $\mathrm{Ru} / \mathrm{CeO}_{2}$, only diffraction patterns assigned to cubic-type $\mathrm{MgO}$ and $\mathrm{CeO}_{2}$ were obtained. In the case of $\mathrm{Ru} / \mathrm{Pr}_{2} \mathrm{O}_{3}$, the diffraction peaks were attributed to rare earth C-type $\operatorname{Pr}_{2} \mathrm{O}_{3}{ }^{33}$ On the other hand, the fact that no diffraction peaks of the Ru species were apparent in the patterns of the 
catalyst samples suggests that the crystallite size of the loaded $\mathrm{Ru}$ was too small to be detected. $\mathrm{NH}_{3}$-synthesis activities of the $\mathrm{Ru}$ catalysts were then measured at $0.9 \mathrm{MPa}$ after reduction at $400{ }^{\circ} \mathrm{C}$. $\mathrm{Ru} / \mathrm{Pr}_{2} \mathrm{O}_{3}$ catalyzed $\mathrm{NH}_{3}$ synthesis at a much higher rate than that of $\mathrm{Ru} / \mathrm{MgO}$ and $\mathrm{Ru} / \mathrm{CeO}_{2}$ at all temperatures from 310 to $390{ }^{\circ} \mathrm{C}$ (Fig. 2). At $390{ }^{\circ} \mathrm{C}$ in particular, the $\mathrm{NH}_{3}$ synthesis rate of $\mathrm{Ru} / \mathrm{Pr}_{2} \mathrm{O}_{3}$ was $15200 \mu \mathrm{mol} \mathrm{g}{ }^{-1} \mathrm{~h}^{-1}$, much higher than that of $\mathrm{Ru} / \mathrm{CeO}_{2}\left(7400 \mu \mathrm{mol} \mathrm{g}^{-1} \mathrm{~h}^{-1}\right)$ and $\mathrm{Ru} / \mathrm{MgO}\left(1500 \mu \mathrm{mol} \mathrm{g}{ }^{-1} \mathrm{~h}^{-1}\right)$. Furthermore, the long-term stability of the $\mathrm{Ru} / \mathrm{Pr}_{2} \mathrm{O}_{3}$ catalyst at $390{ }^{\circ} \mathrm{C}$ under $0.9 \mathrm{MPa}$ was evidenced by the fact that the rate of $\mathrm{NH}_{3}$ synthesis was stable for $50 \mathrm{~h}$ (Fig. S3†).

Specific surface areas of $\mathrm{Ru} / \mathrm{Pr}_{2} \mathrm{O}_{3}, \mathrm{Ru} / \mathrm{CeO}_{2}$, and $\mathrm{Ru} / \mathrm{MgO}$ were $20.4,33.5$, and $46.4 \mathrm{~m}^{2} \mathrm{~g}^{-1}$, respectively (Table 1 ). There was no clear correlation between specific surface area and catalytic activity. Interestingly, the $\mathrm{H} / \mathrm{Ru}$ ratio, a measure of $\mathrm{Ru}$ dispersion, was very low for $\mathrm{Ru} / \mathrm{Pr}_{2} \mathrm{O}_{3}$ compared with that of the other catalysts. As a result, the turnover frequency of $\mathrm{Ru} / \mathrm{Pr}_{2} \mathrm{O}_{3}$ was $>3.5$ times that of $\mathrm{Ru} / \mathrm{CeO}_{2}$ and $\mathrm{Ru} / \mathrm{MgO}$. These results suggest that the high turnover frequency of $\mathrm{Ru} / \mathrm{Pr}_{2} \mathrm{O}_{3}$ makes the excellent rate of synthesis of $\mathrm{NH}_{3}$ (activity per weight of catalyst) possible.

\section{Structural properties of $\mathrm{Ru} / \mathrm{Pr}_{2} \mathrm{O}_{3}$}

As the $\mathrm{NH}_{3}$-synthesis ability of a supported $\mathrm{Ru}$ catalyst is related to the morphology of the loaded Ru and the basicity of the support material, we used scanning transmission electron micrograph (STEM) observations and energy dispersive X-ray (EDX) analysis to investigate the morphology. Fig. 3 and $\mathrm{S} 4 \dagger$ show high-angle annular dark-field (HAADF) images and EDX maps of $\mathrm{Ru} / \mathrm{Pr}_{2} \mathrm{O}_{3}$ following treatment of the catalyst with $\mathrm{H}_{2}$ at $400{ }^{\circ} \mathrm{C}$. Fig. S5 and $\mathrm{S} 6 \dagger$ show analogous images and maps of $\mathrm{Ru} / \mathrm{CeO}_{2}$ and $\mathrm{Ru} / \mathrm{MgO}$, respectively. A number of particles identified as $\mathrm{Ru}$ species by EDX were supported on $\mathrm{MgO}$ and $\mathrm{CeO}_{2}$, but were seldom observed over $\mathrm{Pr}_{2} \mathrm{O}_{3}$. However, the EDX map showed that $\mathrm{Ru}$ was dispersed over the entire $\operatorname{Pr}_{2} \mathrm{O}_{3}$ surface. In the reconstructed overlapping EDX images, the

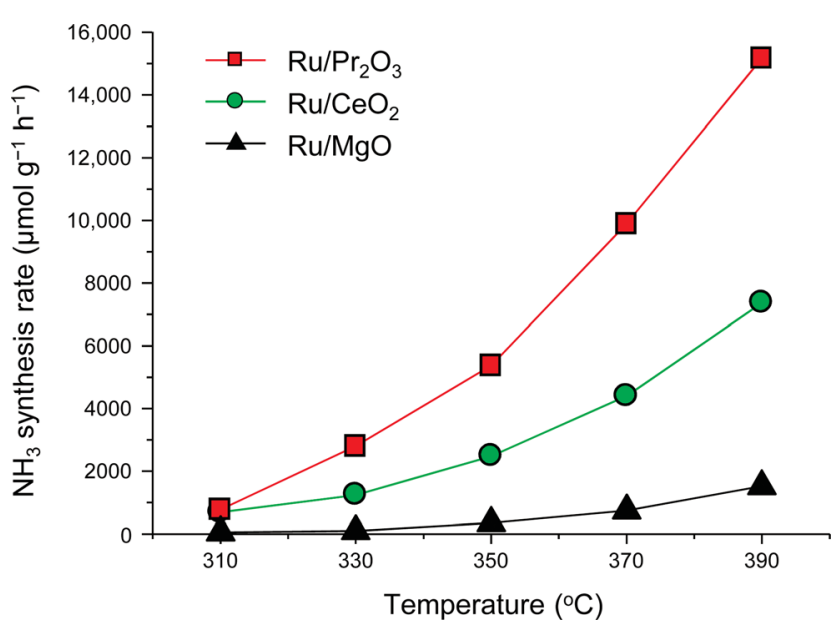

Fig. 2 Rate of $\mathrm{NH}_{3}$ synthesis over supported Ru catalysts. Reaction conditions: catalyst, $0.2 \mathrm{~g}$; reactant gas, $\mathrm{H}_{2} / \mathrm{N}_{2}=3$ with a flow rate of

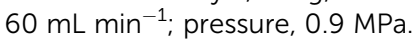

greenish edges of the catalyst particles indicated that the surfaces of the catalyst particles were covered by the Ru species. These results suggest that the state of $\mathrm{Ru}$ is completely different when it is loaded over $\mathrm{Pr}_{2} \mathrm{O}_{3}$ versus $\mathrm{MgO}$ and $\mathrm{CeO}_{2}$. To further investigate the surface morphology, we made high-resolution STEM (HR-STEM) observations (Fig. 4, and see Fig. S7-S9†). On $\mathrm{Ru} / \mathrm{MgO}$ and $\mathrm{Ru} / \mathrm{CeO}_{2}$, the lattice fringes of the $\mathrm{Ru}$ species and the supports were clearly apparent. The $d$ space of the $\mathrm{Ru}$ species was $0.21 \mathrm{~nm}$, which is consistent with that of the (101) plane of metallic $\mathrm{Ru}$. Mean diameters of the $\mathrm{Ru}$ particles were $1.8 \pm 0.7 \mathrm{~nm}$ on $\mathrm{Ru} / \mathrm{MgO}$ and $2.5 \pm 0.8 \mathrm{~nm}$ on $\mathrm{Ru} / \mathrm{CeO}_{2}$. In addition, the surface of the supports of these catalysts was smooth, and changes in the lattice fringe were clearly observed on the boundaries between Ru particles and supports (Fig. $4 \mathrm{~b}$ and c, S8 and $\mathrm{S} 9 \dagger$ ). In contrast, on $\mathrm{Ru} / \mathrm{Pr}_{2} \mathrm{O}_{3}$, the surface of $\operatorname{Pr}_{2} \mathrm{O}_{3}$ was covered by layers of $\mathrm{Ru}$ rather than by particles. The fact that the lattice fringes of most parts of the Ru layers were not apparent indicated that the crystallinity of the Ru layers was low. The thickness of the $\mathrm{Ru}$ layers was $0.5-3 \mathrm{~nm}$, and $\mathrm{Ru}$ particles were sometimes included in the layers. Thus, we considered that the surface of $\operatorname{Pr}_{2} \mathrm{O}_{3}$ was covered mainly with low-crystalline $\mathrm{Ru}$ nano-layers.

To explain why the $\mathrm{Ru}$ on the $\mathrm{Pr}_{2} \mathrm{O}_{3}$ support possessed such a unique morphology, we analysed the X-ray diffraction patterns of the catalyst precursors of $\mathrm{Ru} / \mathrm{Pr}_{2} \mathrm{O}_{3}$. As shown in Fig. S10, $\uparrow$ the bare support [before impregnation with $\mathrm{Ru}_{3}(\mathrm{CO})_{12}$ ] showed the structure of fluorite-type $\operatorname{Pr}_{6} \mathrm{O}_{11}$. However, after impregnation with $\mathrm{Ru}_{3}(\mathrm{CO})_{12}$ in tetrahydrofuran (THF) and drying, the peaks assigned to $\operatorname{Pr}_{6} \mathrm{O}_{11}$ became smaller, and peaks attributed to $\mathrm{Pr}(\mathrm{OH})_{3}$ and $\mathrm{PrOOH}$ appeared. Furthermore, after heat treatment under a stream of Ar at $350{ }^{\circ} \mathrm{C}$, only peaks corresponding to PrOOH were observed. At this point, the HAADF STEM and overlay of the EDX maps of $\mathrm{Ru} / \mathrm{Pr}_{2} \mathrm{O}_{3}$ demonstrated that the surfaces of the catalyst particles were covered by $\mathrm{Ru}$ species (Fig. S11 $\dagger$ ). These results indicate that $\mathrm{Ru}_{3}(\mathrm{CO})_{12}$ reacted with the $\mathrm{O}^{2-}$ in $\mathrm{Pr}_{6} \mathrm{O}_{11}$ and $\mathrm{Pr}^{4+}$ was reduced to $\mathrm{Pr}^{3+}$, with the formation of $\mathrm{CO}_{2}$. The support then reacted with the $\mathrm{H}_{2} \mathrm{O}$ impurity in the THF, and after heat treatment in the Ar stream, $\mathrm{Ru}$ and $\mathrm{PrOOH}$ were formed. In brief, the results reveal that the high reactivity between $\mathrm{Ru}_{3}(\mathrm{CO})_{12}$ and $\mathrm{Pr}_{6} \mathrm{O}_{11}$ prevented aggregation of $\mathrm{Ru}_{3}(\mathrm{CO})_{12}$ with $\mathrm{Ru}_{3}(\mathrm{CO})_{12}$ and contributed to the formation of the unique structure of the loaded $\mathrm{Ru}$. The rough surface of the $\operatorname{Pr}_{2} \mathrm{O}_{3}$ and the fuzziness of the boundary between $\mathrm{Ru}$ and $\mathrm{Pr}_{2} \mathrm{O}_{3}$ in the HR-STEM image in Fig. 4a and $\mathrm{S} 7 \dagger$ was probably due to the reaction between $\mathrm{Ru}_{3}(\mathrm{CO})_{12}$ and $\operatorname{Pr}_{6} \mathrm{O}_{11}$. Furthermore, during $\mathrm{H}_{2}$ treatment, $\mathrm{PrOOH}$ was converted to $\mathrm{Pr}_{2} \mathrm{O}_{3}$ (Fig. S2 $\dagger$ ). During this process, part of the $\mathrm{Ru}$ included in the $\mathrm{Ru}$ layers was crystallized to form $\mathrm{Ru}$ particles, and thus $\mathrm{Ru}$ particles were sometimes observed in the Ru layers in the HRSTEM images (Fig. S7 $\dagger$ ). As shown in the HR-STEM images, the $\mathrm{Ru}$ species over $\mathrm{Pr}_{2} \mathrm{O}_{3}$ were arranged in a low-crystalline, nanolayered structure. In such a structure, unsaturated $\mathrm{Ru}$ atoms were not precisely arranged and formed step-and-terrace sites similar to a $\mathrm{B}_{5}$-type site. The unique surface morphology of $\mathrm{Ru}$ in $\mathrm{Ru} / \mathrm{Pr}_{2} \mathrm{O}_{3}$ would promote $\mathrm{N}_{2}$ adsorption and subsequent cleavage of the $\mathrm{N} \equiv \mathrm{N}$ bond. 
Table 1 Physicochemical properties of supported Ru catalysts

\begin{tabular}{lllll}
\hline Catalyst & Specific surface area $\left(\mathrm{m}^{2} \mathrm{~g}^{-1}\right)$ & $\mathrm{H} / \mathrm{Ru}^{a}$ & Turnover frequency $^{b}\left(\mathrm{~s}^{-1}\right)$ & Density of base sites $^{c}\left(\mu \mathrm{mol} \mathrm{m}^{-2}\right)$ \\
\hline $\mathrm{Ru} / \mathrm{Pr}_{2} \mathrm{O}_{3}$ & 20.4 & 0.17 & 0.050 & 4.4 \\
$\mathrm{Ru} / \mathrm{CeO}_{2}$ & 33.5 & 0.29 & 0.014 & 2.3 \\
$\mathrm{Ru} / \mathrm{MgO}$ & 46.4 & 0.3 & 0.003 & 2.2
\end{tabular}

${ }^{a}$ Estimated by using $\mathrm{H}_{2}$ chemisorption capacity. ${ }^{b}$ Calculated by using $\mathrm{H} / \mathrm{Ru}$ value and $\mathrm{NH}_{3}$ yield at $390{ }^{\circ} \mathrm{C}$ under $0.9 \mathrm{MPa}^{c}{ }^{c}$ Estimated by using $\mathrm{CO}_{2}-$ TPD.
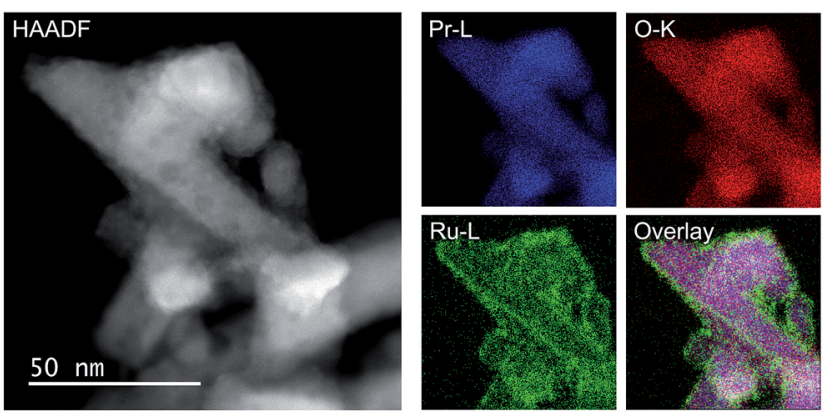

Fig. 3 HAADF-STEM image, Pr-L, O-K, and Ru-L STEM-EDX maps, and reconstructed overlay image of $\mathrm{Pr}, \mathrm{O}$, and $\mathrm{Ru}$ for $\mathrm{Ru} / \mathrm{Pr}_{2} \mathrm{O}_{3}$ after $\mathrm{H}_{2}$ reduction.

In addition, we carried out STEM-EDX observations of $\mathrm{Ru} / \mathrm{Pr}_{2} \mathrm{O}_{3}$ after the long-term stability test shown in Fig. S3. $\dagger$ As shown in Fig. $\mathrm{S} 12$ and $\mathrm{S} 13, \uparrow \mathrm{Pr}_{2} \mathrm{O}_{3}$ was still covered with lowcrystalline Ru nano-layers, as it was before reaction, and distinct changes of the structure were not observable. These results demonstrate the high durability of the unique surface structure of $\mathrm{Ru} / \mathrm{Pr}_{2} \mathrm{O}_{3}$ under the conditions used for $\mathrm{NH}_{3}$ synthesis.

\section{Basic properties of $\mathrm{Ru} / \mathrm{Pr}_{2} \mathrm{O}_{3}$}

We used $\mathrm{CO}_{2}$ temperature-programmed desorption $\left(\mathrm{CO}_{2}\right.$-TPD) measurements of the catalysts (Fig. 5) to evaluate another crucial determinant of $\mathrm{NH}_{3}$-synthesis ability, the basicity of the support. To remove the contribution of the $\mathrm{CO}_{2}$ that remained on the surface even after $\mathrm{H}_{2}$ reduction, we subtracted the $\mathrm{CO}_{2}$ TPD profile without $\mathrm{CO}_{2}$ adsorption from that after $\mathrm{CO}_{2}$ adsorption (see Fig. $\mathrm{S} 14 \dagger$ for original figures). $\mathrm{CO}_{2}$ desorption was observed at $50-680{ }^{\circ} \mathrm{C}$ on $\mathrm{Ru} / \mathrm{Pr}_{2} \mathrm{O}_{3}, 50-600{ }^{\circ} \mathrm{C}$ on $\mathrm{Ru} / \mathrm{CeO}_{2}$, and $50-500{ }^{\circ} \mathrm{C}$ on $\mathrm{Ru} / \mathrm{MgO} . \mathrm{CO}_{2}$ desorption observed in the high temperature region $\left(\geq 300{ }^{\circ} \mathrm{C}\right)$ was greatest on $\mathrm{Ru} / \mathrm{Pr}_{2} \mathrm{O}_{3}$, intermediate on $\mathrm{Ru} / \mathrm{CeO}_{2}$, and least on $\mathrm{Ru} / \mathrm{MgO}$. These results indicate that the basic sites on $\mathrm{Ru} / \mathrm{Pr}_{2} \mathrm{O}_{3}$ are the strongest, and those on $\mathrm{Ru} / \mathrm{MgO}$ are the weakest. We used the total amount of $\mathrm{CO}_{2}$ desorbed as a metric of basic density over the catalysts. $\mathrm{Ru} / \mathrm{Pr}_{2} \mathrm{O}_{3}$ had the highest basic density, $4.4 \mu \mathrm{mol} \mathrm{m}{ }^{-2}$, almost twice that of $\mathrm{Ru} / \mathrm{CeO}_{2}, 2.3 \mu \mathrm{mol} \mathrm{m}^{-2}$, and $\mathrm{Ru} / \mathrm{MgO}$, $2.2 \mu \mathrm{mol} \mathrm{m}{ }^{-2}$. These results reveal that the surface basicity of $\mathrm{Ru} / \mathrm{Pr}_{2} \mathrm{O}_{3}$ was much stronger than that of $\mathrm{Ru} / \mathrm{MgO}$ and $\mathrm{Ru} / \mathrm{CeO}_{2}$. This strong surface basicity results in the most effective electron donation to $\mathrm{Ru}$ and promotes $\mathrm{N}_{2}$ adsorption and subsequent cleavage of the $\mathrm{N} \equiv \mathrm{N}$ bond. Furthermore, we can say that $\operatorname{Pr}_{2} \mathrm{O}_{3}$ is covered by islands of $\mathrm{Ru}$ nano-layers, which allow large amounts of $\mathrm{CO}_{2}$ to adsorb on the surface of uncovered $\operatorname{Pr}_{2} \mathrm{O}_{3}$. Note also that the $\mathrm{CO}_{2}$ desorption temperature and the total density of the basic sites were higher on $\mathrm{Ru} / \mathrm{CeO}_{2}$ than on $\mathrm{Ru} / \mathrm{MgO}$. This difference accounts for the higher $\mathrm{NH}_{3}$-synthesis activity of $\mathrm{Ru} / \mathrm{CeO}_{2}$ than that of $\mathrm{Ru} / \mathrm{MgO}$.

\section{Activation of $\mathrm{N}_{2}$ over $\mathrm{Ru} / \mathrm{Pr}_{2} \mathrm{O}_{3}$}

Finally, to understand the activation of $\mathrm{N}_{2}$ molecules over the $\mathrm{Ru} / \mathrm{Pr}_{2} \mathrm{O}_{3}$ catalyst, we examined the states of the adsorbed $\mathrm{N}_{2}$ with FT-IR techniques. The IR spectra after the addition of $\mathrm{N}_{2}$ to $\mathrm{Ru} / \mathrm{MgO}, \mathrm{Ru} / \mathrm{CeO}_{2}$, and $\mathrm{Ru} / \mathrm{Pr}_{2} \mathrm{O}_{3}$ at room temperature are shown in Fig. 6. The IR spectrum of each catalyst shows a broad peak around 2350 to $2100 \mathrm{~cm}^{-1}$; such peaks are assignable to the stretching vibration mode of the $\mathrm{N}_{2}$ adsorbed with an endon orientation on the $\mathrm{Ru}$ surface..$^{21,23,24}$ Note that the peak absorbance of $\mathrm{N}_{2}$ adsorbed on $\mathrm{Ru} / \mathrm{Pr}_{2} \mathrm{O}_{3}$ occurred at a lower frequency $\left(2178 \mathrm{~cm}^{-1}\right)$ than the corresponding peak absorbances on $\mathrm{Ru} / \mathrm{MgO}\left(2210 \mathrm{~cm}^{-1}\right)$ and $\mathrm{Ru} / \mathrm{CeO}_{2}\left(2189 \mathrm{~cm}^{-1}\right)$. In the spectrum of ${ }^{15} \mathrm{~N}_{2}$ adsorbed on $\mathrm{Ru} / \mathrm{Pr}_{2} \mathrm{O}_{3}$, the peak absorbance was shifted to a lower frequency $\left(2106 \mathrm{~cm}^{-1}\right)$ compared to
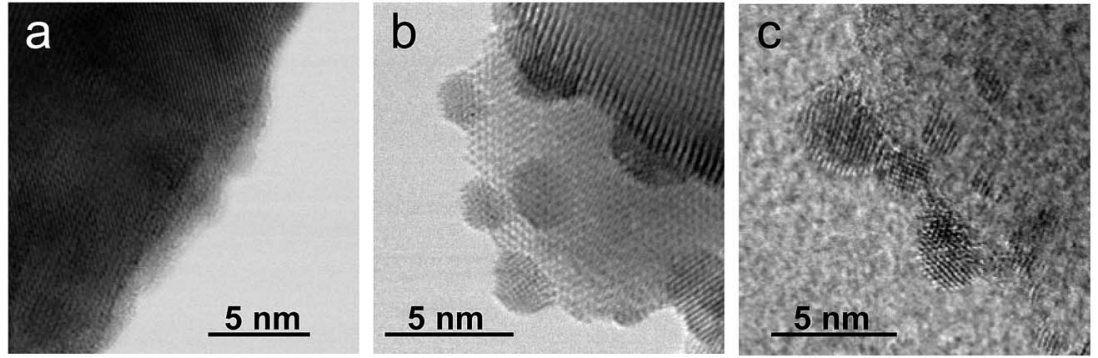

Fig. $4 \mathrm{HR}$-STEM images of (a) $\mathrm{Ru} / \mathrm{Pr}_{2} \mathrm{O}_{3}$, (b) $\mathrm{Ru} / \mathrm{CeO}_{2}$, and (c) $\mathrm{Ru} / \mathrm{MgO}$, after $\mathrm{H}_{2}$ reduction. 


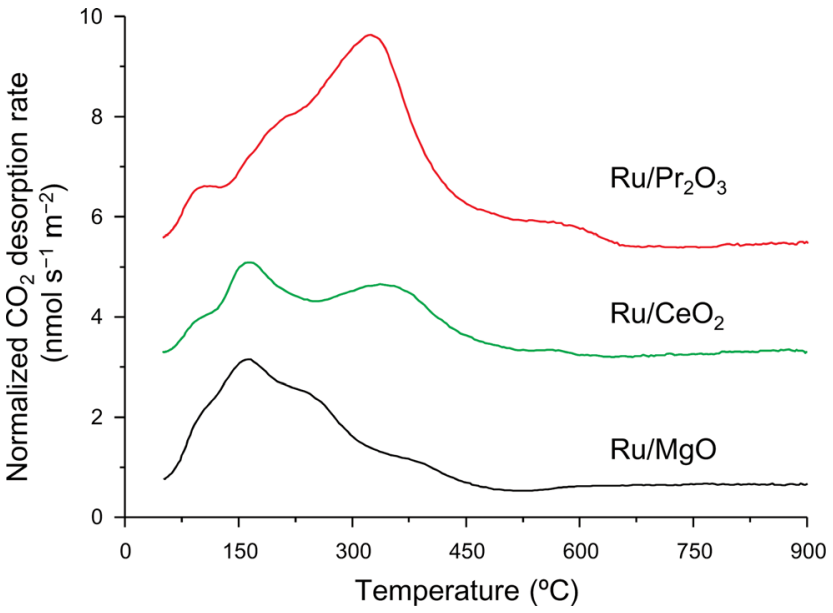

Fig. $5 \mathrm{CO}_{2}$-TPD profiles of supported $\mathrm{Ru}$ catalysts. Following $\mathrm{H}_{2}$ reduction at $400{ }^{\circ} \mathrm{C}, \mathrm{CO}_{2}$ adsorption was carried out at $50{ }^{\circ} \mathrm{C}$. These curves show the difference between the curves shown in Fig. S14 $\uparrow$ to remove the contribution of $\mathrm{CO}_{2}$ that remained on the surface of the catalysts even after $\mathrm{H}_{2}$ pre-treatment.

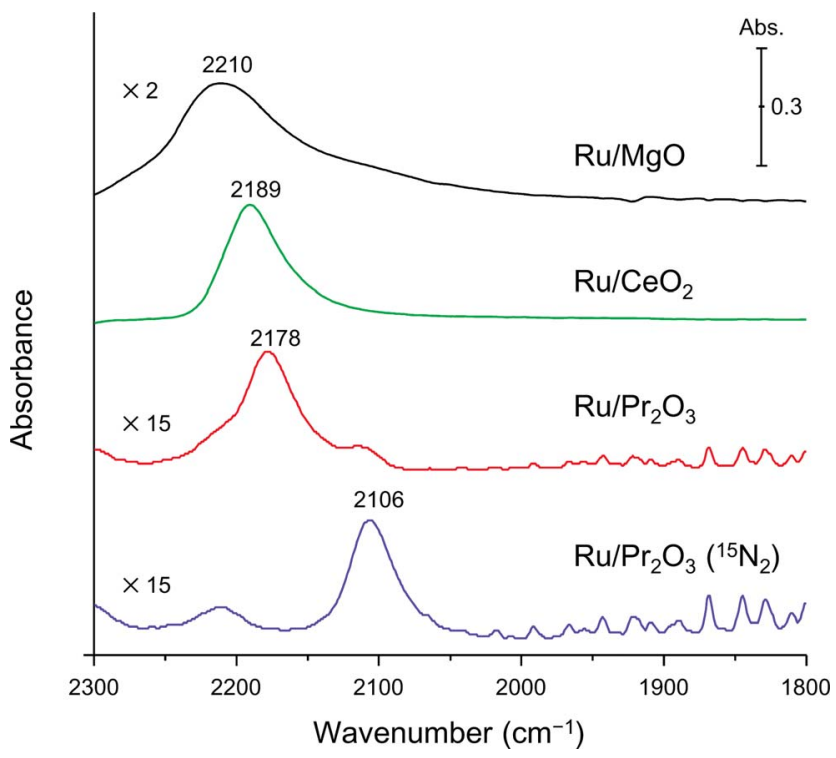

Fig. 6 Difference infrared spectra of $\mathrm{N}_{2}$ molecules (before and after $\mathrm{N}_{2}$ adsorption) on supported $\mathrm{Ru}$ catalysts. Spectra were collected under $6 \mathrm{kPa}$ of $\mathrm{N}_{2}\left({ }^{15} \mathrm{~N}_{2}\right.$ for $\left.\mathrm{Ru} / \mathrm{Pr}_{2} \mathrm{O}_{3}\right)$ at $25^{\circ} \mathrm{C}$.

that on $\mathrm{Ru} / \mathrm{Pr}_{2} \mathrm{O}_{3}\left(2178 \mathrm{~cm}^{-1}\right)$, which is in good agreement with the frequency estimated from the isotope effect $\left(2178 \mathrm{~cm}^{-1} \times\right.$ $\left.(14 / 15)^{1 / 2}=2104 \mathrm{~cm}^{-1}\right) .{ }^{23,24}$ These results suggest that these peaks are associated with the $\mathrm{N}_{2}$ on the Ru surfaces. The lower frequencies of the peak absorbances of $\mathrm{N}_{2}$ adsorbed on $\mathrm{Ru}$ / $\mathrm{Pr}_{2} \mathrm{O}_{3}$ compared to those of $\mathrm{Ru} / \mathrm{MgO}$ and $\mathrm{Ru} / \mathrm{CeO}_{2}$ indicate that the $\mathrm{N} \equiv \mathrm{N}$ bond of $\mathrm{N}_{2}$ was further weakened over the low-crystalline $\mathrm{Ru}$ nano-layers on $\mathrm{Pr}_{2} \mathrm{O}_{3}$ relative to $\mathrm{Ru}$ nanoparticles on the other supports. We surmise that the morphology of the $\mathrm{Ru}$ surface and the basicity of the catalyst contributed synergistically to the weakening of the $\mathrm{N} \equiv \mathrm{N}$ bond and enhanced the catalytic activity for $\mathrm{NH}_{3}$ synthesis.

\section{Conclusions}

In summary, we demonstrated that $\mathrm{Ru} / \mathrm{Pr}_{2} \mathrm{O}_{3}$ without any dopant catalyzed a high rate of $\mathrm{NH}_{3}$ synthesis under mild reaction conditions (0.1-1.0 MPa). Characteristics of $\mathrm{Ru} / \mathrm{Pr}_{2} \mathrm{O}_{3}$ include low-crystalline $\mathrm{Ru}$ nano-layers formed by the reaction between $\mathrm{Ru}_{3}(\mathrm{CO})_{12}$ and $\operatorname{Pr}_{6} \mathrm{O}_{11}$ and strong basicity of $\operatorname{Pr}_{2} \mathrm{O}_{3}$. These characteristics are considered to synergistically accelerate the rate-determining step of ammonia synthesis: cleavage of the $\mathrm{N} \equiv \mathrm{N}$ bond of $\mathrm{N}_{2}$. In addition, substitution of some of the praseodymium with another element without degrading its activity for $\mathrm{NH}_{3}$ synthesis is currently in progress, because $\mathrm{Pr}$ is an expensive element. The outcome of the research will appear in a coming contribution. We believe that our catalyst will facilitate the development of an effective method for synthesizing ammonia from renewable energy under environmentally benign conditions. Such a method can be expected to contribute to the solution of food and energy crises globally.

\section{Acknowledgements}

This work was supported by CREST, Japan Agency of Science and Technology (JST). STEM/TEM observations were performed as part of a program conducted by the Advanced Characterization Nanotechnology Platform Japan, sponsored by the Ministry of Education, Culture, Sports, Science and Technology (MEXT), Japan. K. Sato thanks the Program for the Elements Strategy Initiative for Catalysts \& Batteries (ESICB) commissioned by MEXT. T. Toriyama (Kyushu University) is acknowledged for assistance with STEM/TEM observations. The authors thank Mr Y. Wada, Ms. M. K. Nakao, and Mr T. Terasawa (Oita University) for assistance with sample preparation, catalytic activity tests, and characterization techniques. We acknowledge Prof. K. Shimizu (Hokkaido University) for fruitful discussions concerning IR analysis.

\section{Notes and references}

1 J. W. Erisman, M. A. Sutton, J. Galloway, Z. Klimont and W. Winiwarter, Nat. Geosci., 2008, 1, 636-639.

2 A. Klerke, C. H. Christensen, J. K. Nørskov and T. Vegge, J. Mater. Chem., 2008, 18, 2304-2310.

3 R. Schlogl, ChemSusChem, 2010, 3, 209-222.

4 F. Schüth, R. Palkovits, R. Schlögl and D. S. Su, Energy Environ. Sci., 2012, 5, 6278-6289.

5 J. W. Makepeace, T. J. Wood, H. M. A. Hunter, M. O. Jones and W. I. F. David, Chem. Sci., 2015, 6, 3805-3815.

6 H. Bielawa, O. Hinrichsen, A. Birkner and M. Muhler, Angew. Chem., Int. Ed., 2001, 40, 1061-1063.

7 T. Kandemir, M. E. Schuster, A. Senyshyn, M. Behrens and R. Schlogl, Angew. Chem., Int. Ed., 2013, 52, 12723-12726.

8 S. Perathoner and G. Centi, ChemSusChem, 2014, 7, 12741282.

9 C. W. Hooper, Ammonia Synthesis: Commercial Practice, in Catalytic Ammonia Synthesis, Fundamentals and Practice, ed. J. R. Jennings, Springer, US, 1991, pp. 253-283. 
10 M. Kitano, Y. Inoue, Y. Yamazaki, F. Hayashi, S. Kanbara, S. Matsuishi, T. Yokoyama, S. W. Kim, M. Hara and H. Hosono, Nat. Chem., 2012, 4, 934-940.

11 F. Hayashi, M. Kitano, T. Yokoyama, M. Hara and H. Hosono, ChemCatChem, 2014, 6, 1317-1323.

12 Y. Inoue, M. Kitano, S.-W. Kim, T. Yokoyama, M. Hara and H. Hosono, ACS Catal., 2014, 4, 674-680.

13 S. Gambarotta and J. Scott, Angew. Chem., Int. Ed., 2004, 43, 5298-5308.

14 H. K. Chae, D. Y. Siberio-Perez, J. Kim, Y. Go, M. Eddaoudi, A. J. Matzger, M. O'Keeffe and O. M. Yaghi, Nature, 2004, 427, 523-527.

15 K. Aika, H. Hori and A. Ozaki, J. Catal., 1972, 27, 424-431.

16 K. Aika, M. Kumasaka, T. Oma, O. Kato, H. Matsuda, N. Watanabe, K. Yamazaki, A. Ozaki and T. Onishi, Appl. Catal., 1986, 28, 57-68.

17 S. Dahl, A. Logadottir, R. C. Egeberg, J. H. Larsen, I. Chorkendorff, E. Törnqvist and J. K. Nørskov, Phys. Rev. Lett., 1999, 83, 1814-1817.

18 C. J. H. Jacobsen, S. Dahl, P. L. Hansen, E. Törnqvist, L. Jensen, H. Topsøe, D. V. Prip, P. B. Møenshaug and I. Chorkendorff, J. Mol. Catal. A: Chem., 2000, 163, 19-26.

19 S. Dahl, E. Tornqvist and I. Chorkendorff, J. Catal., 2000, 192, 381-390.

20 Z. Song, T. Cai, J. C. Hanson, J. A. Rodriguez and J. Hrbek, J. Am. Chem. Soc., 2004, 126, 8576-8584.
21 Z. You, K. Inazu, K. Aika and T. Baba, J. Catal., 2007, 251, 321-331.

22 K. Aika, A. Ohya, A. Ozaki, Y. Inoue and I. Yasumori, J. Catal., 1985, 92, 305-311.

23 J. Kubota and K. Aika, J. Chem. Soc., Chem. Commun., 1991, 1544.

24 J. Kubota and K. Aika, J. Phys. Chem., 1994, 98, 11293-11300.

25 K. Aika, T. Takano and S. Murata, J. Catal., 1992, 136, 126140.

26 Y. Horiuchi, G. Kamei, M. Saito and M. Matsuoka, Chem. Lett., 2013, 42, 1282-1284.

27 J. G. van Ommen, W. J. Bolink, J. Prasad and P. Mars, J. Catal., 1975, 38, 120-127.

28 D. E. Brown, T. Edmonds, R. W. Joyner, J. J. McCarroll and S. R. Tennison, Catal. Lett., 2014, 144, 545-552.

29 M. Kitano, Y. Inoue, H. Ishikawa, K. Yamagata, T. Nakao, T. Tada, S. Matsuishi, T. Yokoyama, M. Hara and H. Hosono, Chem. Sci., 2016, 7, 4036-4043.

30 Y. Lu, J. Li, T. Tada, Y. Toda, S. Ueda, T. Yokoyama, M. Kitano and H. Hosono, J. Am. Chem. Soc., 2016, 138, 3970-3973.

31 F. Rosowski, A. Hornung, O. Hinrichsen, D. Herein, M. Muhler and G. Ertl, Appl. Catal., A, 1997, 151, 443-460.

32 Y. Niwa and K.-i. Aika, Chem. Lett., 1996, 25, 3-4.

33 G. Adachi and N. Imanaka, Chem. Rev., 1998, 98, 1479-1514. 